\title{
Microglia receptors and their implications in the response to amyloid $\beta$ for Alzheimer's disease pathogenesis
}

\author{
Deborah Doens ${ }^{1,2}$ and Patricia L Fernández ${ }^{1 *}$
}

\begin{abstract}
Alzheimer's disease (AD) is a major public health problem with substantial economic and social impacts around the world. The hallmarks of AD pathogenesis include deposition of amyloid $\beta(A \beta)$, neurofibrillary tangles, and neuroinflammation. For many years, research has been focused on $A \beta$ accumulation in senile plaques, as these aggregations were perceived as the main cause of the neurodegeneration found in AD. However, increasing evidence suggests that inflammation also plays a critical role in the pathogenesis of AD. Microglia cells are the resident macrophages of the brain and act as the first line of defense in the central nervous system. In AD, microglia play a dual role in disease progression, being essential for clearing $A \beta$ deposits and releasing cytotoxic mediators. $A \beta$ activates microglia through a variety of innate immune receptors expressed on these cells. The mechanisms through which amyloid deposits provoke an inflammatory response are not fully understood, but it is believed that these receptors cooperate in the recognition, internalization, and clearance of $A \beta$ and in cell activation. In this review, we discuss the role of several receptors expressed on microglia in A $\beta$ recognition, uptake, and signaling, and their implications for AD pathogenesis.
\end{abstract}

Keywords: Cytokines, Inflammation, Microglia, Receptor

\section{Background}

Alzheimer's disease (AD) is a neurodegenerative disorder characterized by a progressive decline in cognitive and functional abilities. According to the World Health Organization, more than 35 million people have dementia and this number is expected to increase in the coming years [1]. The neuropathological hallmarks of $\mathrm{AD}$ include extracellular $A \beta$ deposits, intracellular neurofibrillary tangles, and marked inflammation [2-4]. A $\beta$ deposition and tau protein are found in different areas of the brain, leading to synaptic dysfunction, mitochondrial damage, activation of microglia, and neuronal death $[5,6]$. Inflammation in $A D$ is characterized by reactive microglia surrounding $A \beta$ plaques, which maintain an inflammatory status by secreting proinflammatory mediators, contributing to neuronal loss.

\footnotetext{
* Correspondence: pllanes@indicasat.org.pa

${ }^{1}$ Centro de Biología Molecular y Celular de Enfermedades, Instituto de Investigaciones Científicas y Servicios de Alta Tecnología (INDICASAT-AIP), Edificio 219, Clayton, Ciudad del Saber, República de Panamá

Full list of author information is available at the end of the article
}

Microglia constitute the lesser portion of the total glial cell population within the brain and are found in a resting state in the healthy central nervous system (CNS) [7]. Under pathological conditions, activated microglia undergo morphological changes and produce cytokines and chemokines that affect surrounding cells [8]. In AD, microglia cells play an important role in disease progression by clearing $A \beta$ deposits, initiating phagocytic activity, and releasing cytotoxic mediators. Microglia activated by $A \beta$ in vitro induce the expression of proinflammatory cytokines including interleukin (IL)-1 $\beta$, IL-6, IL-8, tumor necrosis factor- $\alpha$ (TNF- $\alpha$ ), chemokines and reactive oxygen and nitrogen species, all of which cause neuronal damage [9-11].

The mechanisms through which amyloid deposits provoke inflammation are not fully understood. Microglia cells express several receptors that cooperate in the recognition, internalization, and clearance of $\mathrm{A} \beta$ and in cell activation. Microglia receptors, such as scavenger receptors (SR-AI/II), CD36, RAGE (receptor for advanced glycosylation endproducts), Fc receptors, TLRs (toll-like 
receptors), and complement receptors are involved in these processes [12-14] (Figure 1). This review will examine the various roles of microglia receptors in the amyloid cascade, and the implications for AD.

\section{Complement receptors}

The complement system is formed of a number of soluble and membrane-associated proteins that interact to opsonize microorganisms and to induce an inflammatory response that contributes to the resolution of the infectious process [15]. The association of the complement system with AD pathology has been known since the 1980s [16]. Proteins of the complement system have been associated with senile plaques in the brains of $\mathrm{AD}$ individuals [17]. Several proteins of the complement system and their corresponding mRNAs are upregulated in the brains of $A D$ patients and seem to be involved in $A \beta$ induced inflammation, senile plaque formation, and $A \beta$ phagocytosis [18].

The activation of the complement system takes place via three main pathways known as classical, alternative, and MB-lectin [18]. Fibrillar $A \beta$ (fA $\beta$ ) activates the classical as well as the alternative pathways with consequent C3 activation, C5a production, and membrane attack complex (MAC) formation [19]. The role of the complement system in the removal of the infectious agent occurs through the activation of a variety of receptors including CR1 (CD35), CR2 (CD21), CR3 (CD11b/CD18), CR4 (CD11c/CD18), and C5aR (CD88 and C5L2). Some of these receptors play a prominent role in the inflammatory response induced in $\mathrm{AD}$ [12].

CR1 is a transmembrane receptor that plays a major role in the regulation of the complement cascade activation. CR1 binds the complement factors $\mathrm{C} 3 \mathrm{~b}$ and $\mathrm{C} 4 \mathrm{~b}$; high levels of this receptor have been detected in the cerebrospinal fluid (CSF) of AD patients [20]. A recent genome-wide association study in a Caucasian population showed an association of some variants of CR1 with late-onset $\mathrm{AD}$ risk, which has drawn increased attention to the role of this receptor in the pathogenesis of $\mathrm{AD}$ [21]. Those CR1 variants were further correlated with characteristic neuroimaging markers of the disease [22]. The association between CR1 and AD risk has been reproduced in case-control studies in other populations [23,24].

Activated microglia have increased expression levels of CR1; activation of this receptor induces neuronal death [25]. These detrimental effects appear to be associated with enhanced superoxide generation and TNF- $\alpha$ and IL-1 $\beta$ production. CR1 expressed on erythrocytes participates in the clearance of peripheral $A \beta$, suggesting that CR1 may play a role in the removal of $A \beta$ in $A D$ [26]. Polymorphisms in the $C R 1$ locus, which constitute a risk for $\mathrm{AD}$, have been correlated with increased levels of $A \beta$ in the CSF [27]. Owing to the role of CR1 in the clearance of $\mathrm{A} \beta$ and regulation of complement activation, it has been suggested that this receptor may have a beneficial effect on the pathogenesis of AD [28], although the mechanisms are unknown.

The complement factor C3 is an essential component of the complement system. It induces phagocytosis of pathogens through interactions with the CR3 receptor. CR3, also known as Mac-1, is expressed in microglia, and upregulation of this receptor has been detected in the brains of AD individuals [29]. Studies have shown that CR3 appears to be involved in the uptake and clearance of $\mathrm{A} \beta$ in vivo and in vitro [30-32]. Fu et al. have recently suggested that CR3 acts together with the scavenger receptor $\mathrm{A}(\mathrm{SR}-\mathrm{A})$ in the uptake of $\mathrm{A} \beta$ [32]. They also

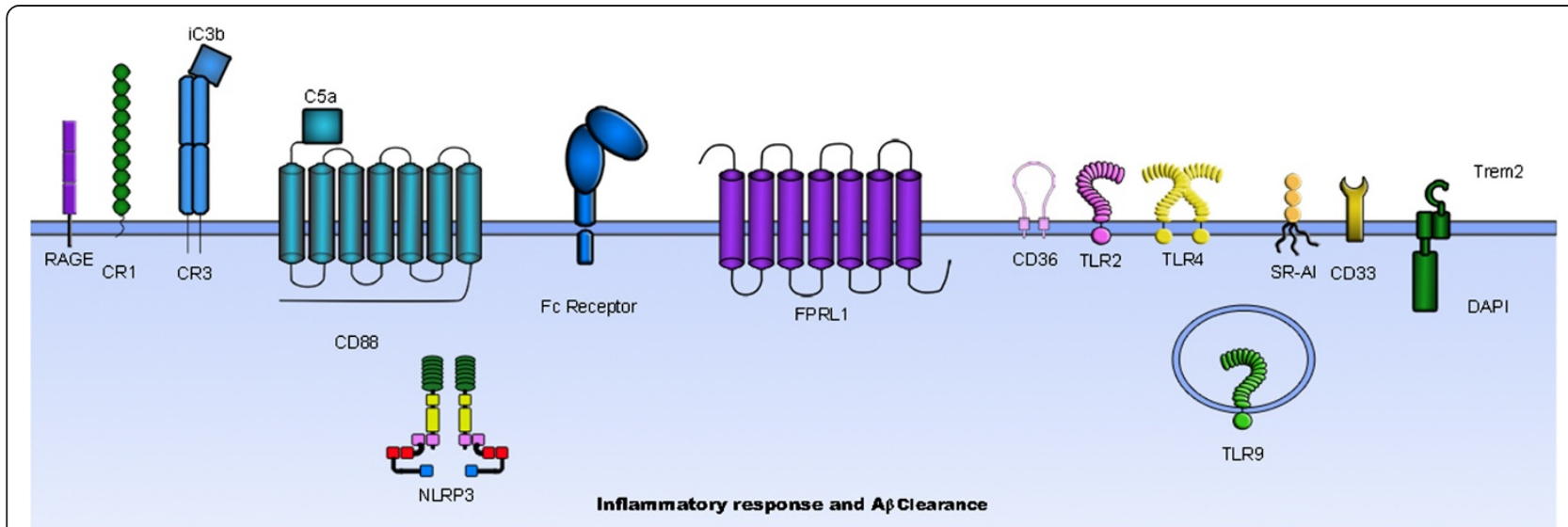

Figure 1 Microglia receptors involved in the amyloid cascade. A variety of microglia receptors are involved in A clearance and in triggering an inflammatory response. Some receptors (RAGE, NLRP3) are mainly implicated in the generation of an inflammatory response by triggering a signaling cascade that results in the production of proinflammatory mediators. Other receptors (SR-Al, TREM2) are involved in the clearance of $A \beta$ by inducing internalization of A $\beta$ fibrils. Some receptors (complement receptors, Fc receptors, FPRL1/FPR2, CD36, TLRs) are involved in both processes. CD33 seems to promote $A \beta$ accumulation. 
showed that murine microglia treated with ligands of SR-A reduced their capacity for $A \beta$ uptake.

CR3 has also been shown to colocalize with $A \beta$ plaques in the brains of $\mathrm{AD}$ patients, providing evidence for a possible direct CR3-A $\beta$ interaction [29]. CR3 is partially involved in $A \beta$ activation of microglia in vivo and in vitro and is implicated in microglia free-radical generation in response to $A \beta$ [33]. These effects appear to be dependent on the binding of $A \beta$ to CR3. Reduced activation was observed in microglia obtained from knockout mice for $\mathrm{CR} 3\left(\mathrm{MACl}^{-/-}\right.$) after in vitro $\mathrm{A} \beta$ challenge compared with microglia derived from control mice [33]. The use of CR3 antagonists has been proposed as a potential therapeutic approach for $\mathrm{AD}$ treatment aimed at reducing the activation of proinflammatory mediators and reactive oxygen species in microglia exposed to $\mathrm{A} \beta$ [33].

$\mathrm{C} 5 \mathrm{a}$ is a highly proinflammatory molecule generated in the process of complement activation. CD88 is a receptor for C5a expressed on the surface of innate immune cells, including microglia. The interaction between $\mathrm{C} 5 \mathrm{a}$ and CD88 leads to the production of inflammatory cytokines, reactive oxygen species, and bioactive amines, among other inflammatory mediators [34]. CD88 is a chemotactic receptor and is involved in the in vitro and in vivo recruitment and activation of microglia [34]. Increased levels of CD88 have been detected in microglia located in the vicinity of amyloid plaques in the brains of AD mouse models [35]. The co-stimulation of human monocytes with $A \beta$ and $C 5$ a induces an increase in IL- $1 \beta$ and IL-6 secretion [36], potentially through a mechanism involving cooperation between microglia receptors. The detrimental role of CD88 in AD has been demonstrated by the use of an antagonist of this receptor, which decreased $\mathrm{A} \beta$ plaques, diminished glia activation, and improved contextual memory in two transgenic AD mouse models [37]. A second receptor for C5a, C5L2, has recently been described as having an increased expression in AD brains compared with normal-aged individuals [38], although its role in AD pathology is still unknown.

Despite this evidence, suggesting a detrimental role of the complement system in $\mathrm{AD}$, some studies have shown that it has beneficial effects in the course of the disease. For example, APP mice deficient in the complement component $\mathrm{C} 3$ exhibited increased $\mathrm{A} \beta$ deposition in the brain, associated with a prominent neuronal loss at 17 months of age [30]. Similarly, overexpression of an inhibitor of the complement in a transgenic mouse model of $A D$ triggered higher deposition of $A \beta$ and increased neurodegeneration compared with controls [39]. Increased C3 mRNA levels have been associated with a reduction in $A \beta$ deposition in mice expressing the human amyloid precursor protein (hAPP) and TGF- $\beta$ [39]. Neuroprotective functions have also been attributed to the products of the complements C3a and C5a [40]. Overall, these results suggest that activation of complement receptors may promote the clearance of $\mathrm{A} \beta$, potentially reducing $A \beta$ accumulation and neurodegeneration in $A D$. More studies are needed to clarify the role of the complement system in the brain and test its potential application to the design of novel $\mathrm{AD}$ treatments.

\section{Fc receptors}

Fc receptors (FcRs) bind the constant domain $(\mathrm{Fc})$ of immunoglobulins (Ig). Specific FcRs exist for each isotype class and sub-class of Ig; for example, IgA is the ligand for $F_{c} \alpha R$, IgD for Fc $\delta R$, IgM for Fc $\mu R$, IgE for Fc $c$ R, and IgG for FcyR [41]. FcR engagement in immune cells activates phagocytosis, degranulation and cytokine and chemokine secretion. FcRs are expressed in brain cells, including microglia, which express all classes of FcRs [41]. Mitogen-activated protein kinases (MAPKs), nuclear factor- $\mathrm{kB}$, Src, and Syk kinases are all involved in the activation of $F_{c} \gamma R$ in microglia $[42,43]$. The role of FcRs expressed in microglia in $\mathrm{AD}$ and healthy brains was first suggested by Peress et al. [44]. There is evidence that Ig bound to neuronal antigens activates a microglial inflammatory response through FcRs expressed on these cells, which may be responsible for the neurodegeneration observed in AD [45].

Active and passive $A \beta$ immunization in studies with $\mathrm{AD}$ animal models has demonstrated an effect of anti$A \beta$ antibodies on $A \beta$ clearance and the reduction of $\operatorname{cog}$ nitive decline [46-48]. FcRs in microglia have been shown to mediate $A \beta$ phagocytosis in the presence of antibodies $[47,48]$. In contrast, other studies have shown that increased $A \beta$ clearance in vivo in the presence of anti-A $\beta$ antibodies is not dependent on FcR-mediated phagocytosis [49]. In addition to Fc-mediated phagocytosis, a non-Fc-mediated disruption of plaque structure occurs in vivo in the presence of antibodies bound to $A \beta$ deposits [50]. Both $\mathrm{A} \beta$ clearance pathways involving antibodies do not seem to be mutually exclusive and might occur in parallel or sequentially.

In addition, increased levels of IgG in the CSF of patients with $\mathrm{AD}$ have been reported [51,52]. In pathological conditions in which the integrity of the blood brain barrier has been compromised, as in the case for $\mathrm{AD}$, Igs may pass through the blood brain barrier, and thereby mediate neurotoxicity and inflammation [53]. Some authors have proposed that there is intra-bloodbrain-barrier synthesis of Igs in patients with AD [51]. However, the role of FcRs in the activation of microglia by naturally produced antibodies during the course of $\mathrm{AD}$ is not well understood.

Fc $\gamma$ Rs expressed on neurons have also been implicated in neurotoxicity and inflammation occurring directly in these cells $[54,55]$. Likewise, a recent study demonstrated that there is a physical interaction between FcyRIIb and $A \beta_{42}$, 
which mediates neurotoxicity [56]. Together, these results do not rule out the possibility of a potential 'crosstalk' between $\mathrm{Fc} \gamma$ Rs and other $\mathrm{A} \beta$ receptors in the cell.

Several hypotheses have tried to explain the use of $A \beta$ immunotherapy as a treatment strategy for AD [57]. One of these hypotheses concerns the role of FcR in mediating phagocytosis of opsonized $A \beta$ by microglia. Several active and passive $A \beta$ immunotherapies are currently being trialed in preclinical and clinical studies. Although these approaches have had an effect on the clearance of $\mathrm{A} \beta$ plaques in $\mathrm{AD}$ patients, little or no improvement has been observed in cognitive performance once extensive neuronal damage has occurred. This topic has recently been reviewed elsewhere [57-59].

The results presented so far demonstrate the complexity of the role that FcRs play in AD progression. Experimental variability, manifested in the variety of animal models used, the timing of the development of AD-like pathology, the use of different antibodies, doses, and routes of inoculation, and other factors, make it difficult to clarify the capacity of these receptors to modulate the development of the disease. Brain cells' responses to antibodies, whether or not they are mediated by FcRs, can have multiple effects on CNS function [60]. Further studies are required to understand the role of FcRmediated $A \beta$ clearance in response to naturally generated antibodies in $\mathrm{AD}$ pathogenesis.

\section{Formyl peptide receptors (FPRs)}

The FPRs are receptors for the bacterial chemotactic peptide fMLP [61]. The FPRs are members of a family of seven transmembrane domains, G-protein-coupled receptors, and are involved in host defense against pathogens and endogenous molecules. Two FPRs have been identified in human beings, FPR1 and FPRL1, along with their counterparts FPR1 and FPR2 in mice. FPRL1 interacts with several host-derived chemotactic agonists, including HIV-1 envelope protein, serum amyloid $A$, and $A \beta_{42}$ [61-63].

FPRL1 interacts with $A \beta_{42}$ through the $\mathrm{N}$-terminus as well as a segment between the fourth transmembrane domain and the third extracellular loop [64]. On mononuclear phagocytes, FPRL1 and FPR2 have been identified as functional receptors for $A \beta_{42}$-induced IL- $1 \beta$ and superoxide secretion $[61,65]$. $A \beta$ induces cell migration and calcium mobilization in HEK293 cells transfected with FPRL1 [61]. The complex A $\beta_{42}$-FPRL1 is internalized into the cytoplasmic compartment of macrophages and HEK293 cells overexpressing FPRL1 [66]. Subtraction of $A \beta_{42}$ from the culture results in a progressive recycling of FPRL1 to the cell membrane, whereas continuous exposure to $A \beta_{42}$ results in intracellular accumulation of $A \beta_{42} /$ FPRL1 complex [66]. Further studies have supported the role of FPRL1 and FPR2 in the endocytosis of $A \beta_{42}[67,68]$.
The expression of FPR2 is increased in primary microglia and N9 cells after lipopolysaccharide (LPS) treatment [69]. LPS-stimulated microglia cells exhibit calcium mobilization and chemotaxis in response to FPR2 agonists including $A \beta_{42}$. Moreover, the stimulation of microglia cells with IFN- $\gamma$ increases FPR2 expression levels and cell migration in response to several FPR2 agonist peptides, such as $A \beta_{42}$ [70]. These results suggest that endogenous or exogenous agents modulate the response to $A \beta$ by regulating the expression of FPR, and point to potential effects on $\mathrm{AD}$ pathology.

FPR2/FPRL1 has been proposed as a potential therapeutic target for $\mathrm{AD}$ based on observations that FPR2 antagonists reduced the proinflammatory response induced by $\mathrm{A} \beta$ in monocytes [71]. However, most studies demonstrating a role of FPRs in A $\beta$ uptake and microglia activation have been performed in vitro; thus, the in vivo relevance of this receptor remains uncertain.

\section{Scavenger receptors}

Scavenger receptors (SR) are structurally diverse cell surface receptors that participate in cellular adhesion and uptake of ligands [72]. Goldstein first described these receptors in 1979 as macrophage receptors with the ability to bind and internalize acetylated low-density lipoproteins (acLDL) and a variety of lipids [73,74]. The SR family can be classified into at least eight classes in mammalian species; most of them are related to atherosclerosis pathogenesis $[75,76]$. Two classes of SR have been described in the CNS. Class A (SR-A) receptors are expressed on microglial and astrocytes and class B scavenger receptor type 2 (also known as CD36) is expressed on microglia and endothelial cells [77,78]. Class A and B SRs have been associated with $\mathrm{AD}$ pathogenesis because both are able to bind and internalize $A \beta$, triggering an inflammatory response [79].

\section{Scavenger receptor $A$}

SR-A type I is a trimeric receptor with a short cytoplasmic tail, a transmembrane region, an $\alpha$ helical coiled domain, a collagenous-like region and a cysteine-rich domain in the C-terminal position [80]. Three isoforms of SR-A have been identified: SR-AI, SR-AII, and SRAIII, all of which are generated by alternative splicing of a single gene $[81,82]$. SR-AI was first described as an acetylated low-density lipoprotein (LDL) receptor but it is now known that it binds to a broad diversity of ligands, such as microbial ligands, acLDL, endotoxins, and $A \beta$ [83-85]. The uptake of ligands by SR-AI is associated with several conditions, including $\mathrm{AD}$ and atherosclerosis $[85,86]$.

SR-AI has been detected on activated microglia in the vicinity of senile plaques from human brain tissue [80]. Evidence shows that SR-AI-binding to $A \beta$ promotes $A \beta$ 
internalization and clearance $[85,87,88]$. The role of SR$A I$ in $A \beta$ clearance was demonstrated by reduced $A \beta$ internalization levels found in mouse microglia treated with neutralizing anti-SR-AI antibodies [88]. Moreover, SR-AI expression levels and $A \beta$ clearance are reduced when microglia activation is sustained for a long period of time [85]. In addition, PS1/APP transgenic mice with a SR-AI deficiency have increased $A \beta$ deposition levels in the brain, which are, in turn, associated with an increase in mortality [89]. Thus, owing to its role in $A \beta$ internalization and clearance, the upregulation of SR-AI expression has been proposed as a possible therapeutic target for AD.

\section{CD36 receptor}

CD36 is a type B scavenger receptor found in a variety of cell types, such as macrophages [90], dendritic cells [91], microglia [77], adipocytes [92], platelets [93], endothelial cells [94], and sensory cells of the retina [95]. CD36 was first described as a thrombospondin receptor and as a receptor for other molecules containing the thrombospondin-type repeat domain [96]. The CD36 receptor consists of an extracellular domain and two cytoplasmic fragments containing the C-terminal and $\mathrm{N}$-terminal domains [97]. CD36, considered a pattern recognition receptor, recognizes exogenous molecules, such as microbial components [98], as well as endogenous molecules, such as low-density lipoproteins, oxidized phospholipids [99], apoptotic cells, and A $\beta$ [90]. CD36 has been implicated in the pathogenesis of several diseases, including AD [13], atherosclerosis [100], and malaria [101], and has been identified as an endogenous negative regulator for angiogenesis [94].

The role of CD36 in AD has been demonstrated by its effect on microglia recruitment [102] and activation in response to $f A \beta[77,102,103]$. Decreases in cytokine and chemokine expression (MCP-1, IL-1 $\beta$, MIP- $1 \alpha$, MIP1 $\beta$, MIP-2, TNF $\alpha$, and $\mathrm{KC}$ ) have been observed in macrophages and microglia from CD36-deficient mice stimulated with $f A \beta$ [102]. Notably, there was elevated expression of CD36 in human brains with $A \beta$ deposits, whereas CD36 was undetectable in healthy brains without $\mathrm{A} \beta$ deposition [104].

In addition, CD36 forms complexes with other pattern recognition receptors to bind fibrillar proteins. The first complex identified in microglia for $\mathrm{fA} \beta$ recognition was composed of CD36, $\alpha_{6} \beta_{1}$ integrin and CD47 [105]. Arrangement of this complex was shown to activate a tyrosine-kinase signaling cascade that led to reactive oxygen species (ROS) production, cytokine expression, and phagocytosis induction. Recent evidence indicates that CD36 also forms a complex with TLR4 and TLR6 [106]. CD36 acts as a co-receptor of TLR4 and TLR6, providing signals for assembly of the CD36-TLR4-TLR6 complex and subsequent activation of the TLRs signaling cascades.

In summary, these results demonstrate that CD36 is a key element for $\mathrm{fA} \beta$-induced microglia and macrophage activation. Recently, a cell-based assay was developed to screen for small molecules that inhibit binding between $A \beta$ and CD36 [107]. This bioassay identified ursolic acid as an inhibitor of the $A \beta-C D 36$ interaction and ROS production in Chinese hamster ovary cells expressing human CD36. Thus, the inhibition of $A \beta-C D 36$ binding is a potential strategy for interrupting the pathogenic processes induced by $A \beta$.

\section{Receptor for advanced glycosylation endproducts (RAGE)}

RAGE was originally described as a receptor of advanced glycosylation endproducts (AGE), which is formed when a reduced sugar, such as glucose, reacts with proteins [108]. RAGE was later described as a multiligand receptor member of the immunoglobulin super family, which is able to bind $\mathrm{S} 100$ proteins, high mobility group box 1 , $\mathrm{A} \beta$ peptide, and $\beta$-sheet fibrils, among other ligands [109-111]. RAGE is expressed in endothelial cells, macrophages, smooth muscle cells, and neurons [112]. RAGE is implicated in the transport of $A \beta$ through the blood brain barrier [113]. A $\beta$ induces NF- $\mathrm{kB}$ activation in neurons, microglia, and endothelial cells, and promotes the production of proinflammatory molecules through the interaction with RAGE $[114,115]$. Several studies have revealed that neuronal dysfunction and inflammatory processes found in $\mathrm{AD}$ are linked to microglia activation by $\mathrm{A} \beta$ recognition through RAGE [113,116-118]. Moreover, it has been suggested that RAGE interacts physically and functionally with FPRL1 to transduce signaling in glia cells [119].

Evidence indicates that the interaction between RAGE expressed on brain endothelial cells and $A \beta$ leads to the activation of MAPKs, c-Jun N-terminal kinases, and extracellular signal-regulated kinases (ERKs) [120]. The activation of these pathways promotes endothelial matrix metalloproteinase-2 production, which is associated with the vascular inflammatory responses also found in $A D$ [120]. Evidence suggests that microglia activation by the RAGE-A $\beta$ interaction also involves the p38 MAPK signaling pathways $[111,117]$. Fang and colleagues demonstrated that microglia overexpression of RAGE in a transgenic $\mathrm{AD}$ animal model (transgenic $\mathrm{mAPP}$ ) increased the production of proinflammatory mediators such as IL-1 $\beta$ and TNF- $\alpha$ after $A \beta$ stimulation. This increase was associated with higher levels of phosphorylated p38 and ERK1/2 [111]. Accordingly, the elevated levels of proinflammatory molecules due to microglia RAGE-A $\beta$ interaction are likely to cause the neuronal damage that leads to deficits in learning and memory. However, early studies 
demonstrated that RAGE-A $\beta$ interactions on the surface of neurons mediate neurotoxicity by inducing oxidative stress [121].

Some research groups have focused on identifying small molecules that might be able to block the A $\beta$ RAGE interaction as a possible therapeutic strategy. Pfizer reached phase II clinical trials for the small molecule RAGE-A $\beta$ inhibitor, called PF-04494700, as an AD pharmacotherapeutic [122]. Later, trials were discontinued when it was confirmed that the treatment did not produce significant effects on secondary outcomes. More recently, a small molecule (FPS ZM1) was discovered that was capable of blocking this interaction in vitro by binding to the RAGE V domain, inhibiting its ability to recognize $A \beta$ and resulting in a reduction in cellular oxidative stress [123].

\section{Toll-like receptors (TLRs)}

TLRs are a family of membrane proteins that recognize a variety of molecules referred to as danger- and pathogen-associated molecular patterns. Toll receptors were first described in Drosophila melanogaster for their role in embryo development and the response to fungal infection in adult flies $[124,125]$. In mammals, 12 TLRs have been described and are expressed in a variety of cells, including microglia and astrocytes [126,127]. The activation of TLRs triggers different signaling pathways, leading to the production of proinflammatory mediators, such as cytokines, nitric oxide, and ROS [128].

Microglia expression of TLRs in the CNS is crucial as a first line of defense against exogenous and endogenous molecules [126]. Microglia express TLRs 1 to 9, and most of these receptors have been associated with microglia activation and neurotoxicity in both mice and human beings $[127,129]$. High levels of mRNA for TLR2, TLR4, TLR5, TLR7, and TLR9 have been detected in plaqueassociated brain tissue of APP23 transgenic mice [130]. TLRs have been implicated in $A \beta$ signaling, where they trigger an intracellular cascade, resulting in the production of proinflammatory molecules and the uptake and clearance of $A \beta[131,132]$.

TLR4 has traditionally been described as a LPS receptor [133] but is capable of recognizing other endogenous and exogenous molecules [134,135]. Several studies have pointed to the importance of microglia activation through the TLR4 pathway $[132,136,137]$. In addition to the role of TLR4 in recognizing LPS by microglia, studies have shown its relevance in response to microglia- $\mathrm{A} \beta$ activation [138]. The activation of murine microglia by $A \beta$ depends on a functional TLR4 coupled with CD14 and myeloid differentiation protein 2 [138]. This microglia activation was implicated in neurotoxicity based on observations of a decrease in the death of hippocampal neurons cell cultures after contact with supernatant of $\mathrm{A} \beta$-stimulated microglia from TLR4 mutated mice [138].

Microglia cells stimulated with TLR4 ligands, such as LPS, showed an increase in $\mathrm{A} \beta$ uptake in vitro [132]. In addition, mice with a deficient lipopolysaccharide response (Tlr $4^{\text {Lps-d }}$ ) showed an increase in $\mathrm{A} \beta$ load in vivo and a decrease in $A \beta$ uptake by microglia in vitro [132]. Taken together, these findings suggest that TLR4 might be involved in the clearance of $\mathrm{A} \beta$. Furthermore, in vivo experiments with a TLR4-mutated AD mouse model showed spatial learning deficits and elevated levels of $\mathrm{A} \beta_{42}$ in the brain [137].

A recent study suggested that the monophosphoryl lipid A (MPL), a TLR4 agonist with lower toxicity than LPS, acts as an A $\beta$ clearance booster [139]. MPL induced a mild inflammatory response in microglia while increasing the ability of these cells to internalize $A \beta$, a mechanism that involves the activation of p38 and the expression of the SR-AI [139].

Overall, these results suggest different roles for TLR4 signaling, which appear to be associated with both beneficial (clearance of $A \beta$ ) and detrimental (neurotoxicity) processes. Different therapeutic approaches for AD can be addressed to overcome the detrimental functions of TLR4. Blocking TLR4 signaling would inhibit microglia activation, thus reducing cytokine production, but would impair $A \beta$ uptake and increase $A \beta$ deposition. On the other hand, the induction of TLR4 signaling through MPL-like activation could increase $A \beta$ uptake with reduced production of proinflammatory cytokines.

TLR2 has also been implicated in the inflammatory response of microglia to $A \beta$. Increased levels of mRNA for TLR2 have been found in the brains of AD patients and AD mouse models [140,141]. Activation of TLR2 in microglia cells by peptidoglycan increases $A \beta$ internalization, inducing the G-protein-coupled receptor FPR2 [141]. Deficiency of TLR2 in a mAPP mouse model led to impaired spatial and nonspatial memory after the third month [142]. In vitro experiments using microglia from TLR2 knockdown mice showed a reduction in the expression of TNF- $\alpha$, iNOS, IL-1 $\beta$, IL-6, CD11a, CD11b, and CD68 in response to $A \beta$ [143]. TLR2 knockdown mice have a deficiency in the expression of proinflammatory molecules in cortical sections after microinjection of fibrillar $A \beta_{1-42}$ into the cortex [143]. Moreover, colocalization of $A \beta_{42}$ and TLR2 has been shown in primary murine microglia, while the leucine-rich repeat on the $\mathrm{N}$-terminal ectodomain has been identified as the ligand receptor interaction site [144].

Liu et al. have also shown that TLR2-deficient bone marrow in chimeric APP transgenic mice treated with $A \beta$ underwent a reduction in the inflammatory response and an increase in $A \beta$ internalization by phagocytosis [144]. Thus, TLR2 inhibition could slow AD pathogenesis 
by reducing inflammation and enhancing $\mathrm{A} \beta$ clearance. However, TLR2 inhibition might interfere with the inflammatory response to other pathogens recognized by this receptor, making it an unlikely therapeutic target.

Increased expression of CD14, TLR2, and TLR4 in AD human brains and animal models has highlighted their role in AD pathology [145]. Treating human monocytes and murine microglia with neutralizing antibodies for CD14, TLR2, and TLR4 followed by fA $\beta$ stimulation reduces $\mathrm{fA} \beta$ binding to cells and the phagocytic response [145]. Microglia cultures from CD14 ${ }^{-/-}, \mathrm{TLR}_{4}^{-/-}$, or $\mathrm{TLR}^{-/-}$mice treated with $\mathrm{fA} \beta$ showed a reduction in ROS production, which links these receptors to the oxidative response induced by $A \beta$. These deficient cells did not activate $p 38$ MAPK in response to $\mathrm{AA} \beta$, implicating this pathway in $\mathrm{fA} \beta$ signaling and microglia activation through TLRs [145]. Further evidence has been provided by studies that showed a reduction in IL-1 $\beta$ and TNF- $\alpha$ production induced by $\mathrm{fA} \beta$ in microglia after $\mathrm{p} 38$ inhibition [146].

TLR9 is another member of the TLR family that is highly expressed when microglia are stimulated with $A \beta$. Activation of N9 microglia with the TLR9 ligand unmethylated cytosine-guanosine $(\mathrm{CpG})$ increases $A \beta$ uptake through a mechanism that involves the upregulation of FPR2 [147]. A study using a microglia-neuron coculture system showed that pre-treating microglia with $\mathrm{CpG}$ attenuated the neurotoxicity caused by $\mathrm{A} \beta$ oligomers [148]. Intracerebroventricular administration of $\mathrm{CpG}$ and $\mathrm{A} \beta$ oligomers in a transgenic $\mathrm{AD}$ model resulted in improvements in cognitive impairment [148]. These results suggest a beneficial role of TLR9 expression in $\mathrm{AD}$ pathogenesis.

Overall, research on TLRs suggests that these receptors play a dual role in AD pathogenesis. TLRs are neuroprotective, owing to their contribution to $A \beta$ clearance. Conversely, TLR-triggered inflammatory responses by $A \beta$ can lead to neurotoxic effects. TLRs 2, 4 and 9 have been suggested as therapeutic targets for AD treatment $[139,144,148]$. However, considering the role of TLRs in the innate immune response to microbial infections and danger signals, modulation of TLR signaling as a potential therapeutic approach presents significant challenges.

\section{NOD-, LRR- and pyrin domain-containing 3 (NLRP3) inflammasome}

Inflammasomes are intracellular multiprotein complexes that sense exogenous and endogenous molecules and are involved in the first line of defense. NLRP3 belongs to the family of the nucleotide-binding domain leucine-rich repeat (LRR)-containing receptors (NOD-like receptors, NLRs) and is a core component of one of the inflammasome complexes. NLRP3 is activated for a variety of molecules including bacterial RNA, toxins, viruses, ATP, uric acid, $A \beta$, asbestos, silica, and alum [149-151]. This complex is composed of an NLR protein (NLRP3), the adaptor molecule apoptotic speck-containing protein with a card (ASC), and pro-caspase-1. Inflammasomes are the platforms for caspase- 1 activation, which mediates the cleavage of inactive IL- $1 \beta$ and IL-18 precursors, an essential step in the secretion of mature cytokine [152].

Activation of microglia cells by $A \beta$ induces the release of the cytokine IL-1 $\beta$ [153]. The first evidence for the role of NLRP3 in IL-1 $\beta$ secretion in AD was provided by Halle et al., who showed that NLRP3 dependent caspase-1 activation occurred in microglia cells after stimulation with $A \beta$ [149]. These authors demonstrated that bone-marrow macrophages from NLRP3-deficient mice failed to release IL- $1 \beta$ in response to $A \beta$ stimuli, and inhibition of $A \beta$ phagocytosis diminished NLRP3mediated IL-1 $\beta$ release in vitro [149]. These results indicate that $A \beta$ phagocytosis is necessary for NLRP3 inflammasome induction of IL-1 $\beta$. Phagocytosis of $A \beta$ induces lysosomal destabilization and dysfunction, with a consequent cytosolic release of lysosomal enzymes, such as cathepsin B [149]. Cathepsin B seems to be involved in NLRP3 dependent caspase- 1 activation, IL-1 $\beta$ secretion and the subsequent release of several proinflammatory and chemotactic mediators [149].

There is an increase in caspase- 1 processing in $\mathrm{AD}$ individuals, corroborating the role of inflammasome activation in AD [154]. The role of NLRP3 in AD has also been confirmed in $\mathrm{AD}$ animal models. APP/PS1/NLRP3 ${ }^{-/-}$and $\mathrm{APP} / \mathrm{PS} 1 / \mathrm{Casp}^{-/-}$mice showed reductions in $\mathrm{A} \beta$ deposition and in spatial memory impairment compared with APP/PS1 animals [154].

The NLRP3 inflammasome has also been related to the CD36 receptor. CD36 has been shown to play a role in inflammasome activation in $\mathrm{AD}$, atherosclerosis and type 2 diabetes $[106,155]$. Recognition of oxidized LDL, $\mathrm{A} \beta$, and amylin peptides by CD36 triggers TLR4-TLR6 heterodimer assembly, creating the first signal for NLRP3 activation. CD36 also mediates the internalization of these ligands into the lysosomal compartment, sending a second signal for NLRP3 activation [106,155]. These results further illustrate the cooperation between immune receptors in the response to $\mathrm{A} \beta$ in $\mathrm{AD}$ (Figure 2).

\section{Other receptors}

Other receptors are involved in $\mathrm{AD}$ pathogenesis, such as CD33 and the triggering receptor expressed by myeloid cells 2 (TREM2). Recently, a genome-wide analysis identified different $\mathrm{AD}$ risk alleles, including a gene encoding the human protein CD33 [156]. CD33 is a transmembrane protein, a member of the sialic acid-binding immunoglobulin-like lectins, and is expressed in myeloid progenitor cells, including in microglia cells [157-159]. A recent analysis of post-mortem brain samples of patients 


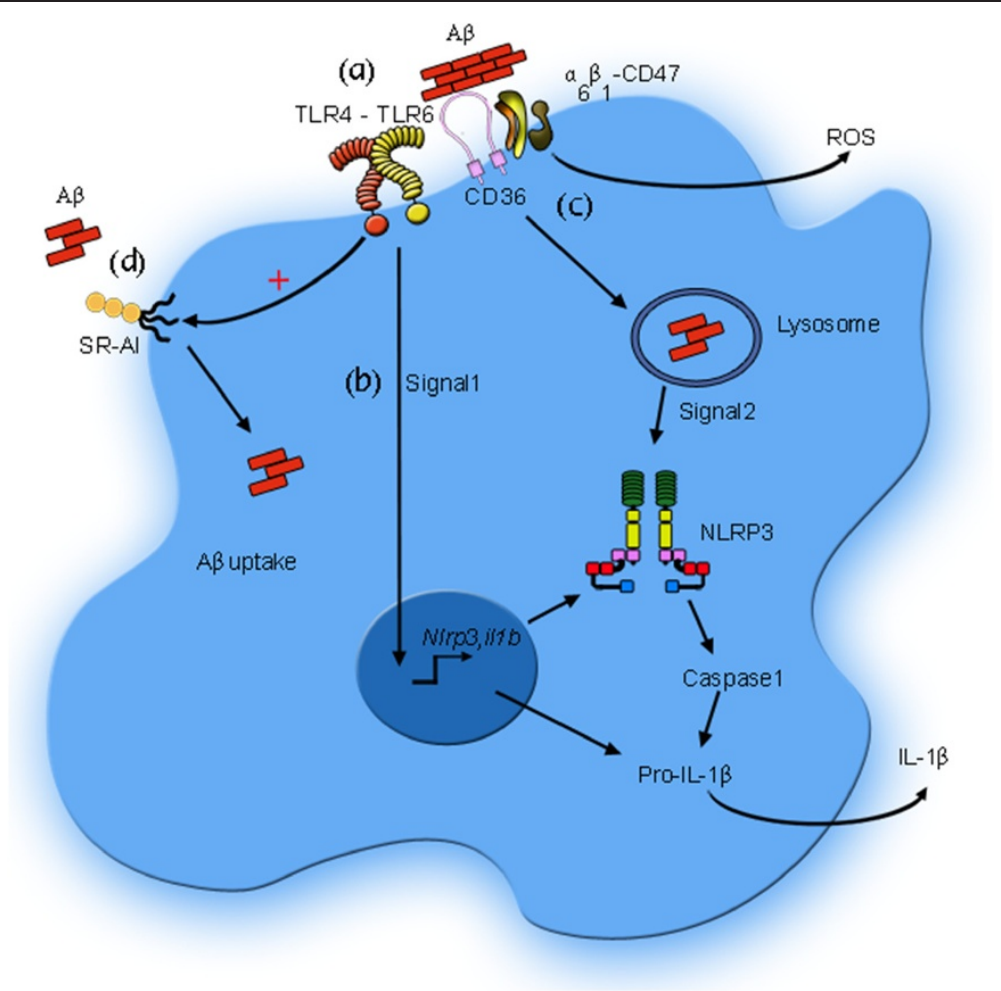

Figure 2 Cooperation among microglia receptors in $A \beta$ recognition, uptake and signaling. (a) $A \beta$ fibrils are recognized by the complex CD36- $\alpha_{6} \beta_{1}-C D 47$, generating ROS production. The interaction between CD36 and A 3 provides signals for the assembly of the heterodimer TLR4-TLR6 complex. (b) CD36-TLR4-TLR6 complex activation constitutes the first signal for the transcription of Nlrp3 and il/b. (c) CD36 mediates the internalization of $A \beta$ into the lysosomal compartment. Lysosomal disruption constitutes the second signal for the NLRP3 assembly and the subsequent cleavage of pro-IL-1 $\beta$, rendering the mature IL-1 $\beta$. (d) The activation of TLR4 also induces the overexpression of SR-Al, which contributes to the clearance of $A \beta$.

Table 1 Summary of microglia receptors and their effects in AD pathogenesis

\begin{tabular}{|c|c|c|c|}
\hline Receptors & Expression in brain cells & Role in AD pathogenesis & References \\
\hline Complement receptors & $\begin{array}{l}\text { Neurons, microglia, astrocytes and } \\
\text { oligodendrocytes }\end{array}$ & $\begin{array}{l}\text { Microglia activation, cytokine expression and } \\
A \beta \text { clearance }\end{array}$ & {$[25,26,28,30,31,33,34,37]$} \\
\hline Fc receptors & $\begin{array}{l}\text { Neurons, microglia, astrocytes and } \\
\text { oligodendrocytes }\end{array}$ & Inflammatory response and $A \beta$ clearance & {$[41,45]$} \\
\hline FPRL1/FPR2 & Microglia, astrocytes & $\begin{array}{l}\text { Microglia activation, inflammatory response and } \\
A \beta \text { internalization }\end{array}$ & {$[61,65,66,68,71,167]$} \\
\hline SR-A & Microglia, astrocytes & $A \beta$ internalization and clearance & {$[85,88]$} \\
\hline CD36 & Neurons, microglia, astrocytes & Microglia recruitment, activation and $A \beta$ phagocytosis & {$[77,102,106,155]$} \\
\hline RAGE & Neurons, microglia and astrocytes & Microglia activation and cytokine expression & {$[113,115-118]$} \\
\hline TLR & Microglia, astrocytes & $\begin{array}{l}\text { Microglia activation, inflammatory response and } \\
A \beta \text { clearance }\end{array}$ & {$[131,132,139,143-145,148]$} \\
\hline NLRP3 & Microglia & Cytokine expression & {$[149,153]$} \\
\hline CD33 & Microglia & Impairs microglia $A \beta$ clearance & {$[159,160]$} \\
\hline TREM2 & Microglia, neurons & A $\beta$ clearance & {$[162-166]$} \\
\hline
\end{tabular}

$A \beta$, amyloid $\beta ; A D$, Alzheimer's disease; FPR, formyl peptide receptors; NLRP, nod-like-receptor protein; RAGE, receptor for advanced glycosylation endproducts; SR-A, scavenger receptor A; TLR, toll-like receptor; Trem2, triggering receptor expressed by myeloid cells 2 . 
with $\mathrm{AD}$ showed high expression levels of $\mathrm{CD} 33$ in microglia surrounding $A \beta$ plaques [160]. In vitro assays revealed a negative relationship between $\mathrm{CD} 33$ levels and $\mathrm{A} \beta$ clearance [160]. Specifically, CD $33^{-/-}$microglia showed an enhanced capacity to internalize $A \beta$, whereas the overexpression of $\mathrm{CD} 33$ impaired $\mathrm{A} \beta$ uptake. AD mice deficient in $\mathrm{CD} 33$ exhibited a reduction in $A \beta$ plaques, suggesting that CD33 favors $A \beta$ accumulation [160].

TREM2 is a transmembrane protein that forms a complex with the TYRO protein tyrosine-kinase-binding protein, also known as Dap12. TREM2 is expressed in microglia and neurons and appears to be involved in promoting phagocytosis and in inhibiting the production of inflammatory mediators by these cells [161-163]. TREM2 and its adaptor protein Dap12 are highly expressed in amyloid plaque-associated microglia in APP23 transgenic mice [164]. The role of TREM2 in AD has also been demonstrated in an exome sequencing and whole genome sequencing study $[165,166]$. A rare mutation in exon 2 of TREM2, which encodes for a substitution of histidine for arginine at position 47, represents a risk factor for late-onset $\mathrm{AD}[165,166]$. The loss of function of TREM2 due to this mutation is thought to be the main source of the pathogenic effect of the risk variant [165]. Clinical evidence has shown that carriers of this variant performed worse in cognitive tests than noncarriers and were more susceptible to the development of late-onset CNS diseases [165]. To date, there is an incomplete understanding of specific TREM2 ligands and functions, which makes it difficult to determine the contribution of TREM2 variants to $A D$ progress.

\section{Conclusions}

Existing drugs for $\mathrm{AD}$ only treat the symptoms of the disease but do not decelerate or cure AD. Furthermore, the last drug to be approved by the Food and Drug Administration for therapeutic AD treatment was memantine, in 2003. In the last decade, several candidate drugs have failed to reach statistical significance in their primary outcomes. The drugs currently under test in clinical trials are cholinesterase inhibitors, N-methyl-Daspartate antagonists, inhibitors of $A \beta$ aggregation, and $\mathrm{A} \beta$ immunotherapies.

In recent years, the role of microglia in $\mathrm{AD}$ pathology has received more attention. In $A D$, microglia are activated by $A \beta$, generating a proinflammatory response sustained over time that can cause neuronal death. The damaged neurons release signals that can overactivate microglia, inducing a cycle of neuron damage; this process is known as reactive microgliosis. The $\mathrm{A} \beta$-induced microglia activation pathways are not well understood but the involvement of several receptors in this process is evident. The data discussed here suggest that microglia receptors play a redundant role in the activation of microglia by $A \beta$.
It is unlikely that a single pathway is involved; rather, multiple pathways likely contribute to $\mathrm{AD}$ pathogenesis. Table 1 summarizes the receptors discussed here and their potential effects in $\mathrm{AD}$ pathogenesis.

Over the last decade, advances have been made in understanding the signal transduction pathways involved in the expression of proinflammatory molecules in $\mathrm{AD}$. Phosphorylation and activation of specific intracellular kinases represent common events in the signaling cascades triggered in $A \beta$ responses. Therefore, those signaling molecules can also be considered targets for new $\mathrm{AD}$ drugs. The therapeutic targeting of microglia receptors implicated in the response to $A \beta$ and their associated signaling pathways could reduce the inflammation found in $\mathrm{AD}$. Further studies are necessary to better understand all the molecular mechanisms occurring in this response, so as to establish new therapeutic strategies. The available data strongly suggest that modulating microglia activation and neuroinflammation through microglia receptors could attenuate the $A \beta$-induced neurodegeneration found in $\mathrm{AD}$ patients. However, the immune status and the stage of disease progression are critical factors to consider. The data reviewed here support a multitargeted immunomodulation approach as a potential treatment to mitigate $\mathrm{AD}$ progression and symptoms.

\section{Abbreviations}

Aß: amyloid $\beta$; acLDL: acetylated low-density lipoproteins; AD: Alzheimer's disease; AGE: advanced glycosylation endproducts; APP: amyloid precursor protein; CNS: central nervous system; CpG: cytosine-guanosine;

CSF: cerebrospinal fluid; ERK: extracellular signal-regulated kinases; $\mathrm{fA}$ : fibrillar amyloid $\beta ;$ FCR: Fc receptor; FPR: formal peptide receptor; Ig: immunoglobulin; LDL: low-density lipoprotein; LPS: lipopolysaccharide; LRP: LDL receptor-related protein; LRR: leucine-rich repeat; MAC: membrane attack complex;

MAPK: mitogen-activated protein kinase; MPL: monophosphoryl lipid A;

NLR: NOD-like receptor; NLRP3: NOD-, LRR- and pyrin domain-containing 3; RAGE: receptor for advanced glycosylation endproducts; ROS: reactive oxygen species; SR: scavenger receptor; TLR: toll-like receptor; TNF-a: tumor necrosis factor-a; Trem2: triggering receptor expressed by myeloid cells 2 .

\section{Competing interests}

The authors do not have any competing interests.

\section{Authors' contributions}

Both authors prepared the manuscript and figures and approved the final manuscript.

\section{Acknowledgements}

The authors' work is supported by Secretaria Nacional de Ciencia Tecnología e Innovación of the Republic of Panama and in part by the Sistema Nacional de Investigacion. We thank Dr. Gabrielle Britton and Colleen Goodridge for critical review of the manuscript and Rita M. Giovanni for her assistance with the figures.

\section{Author details}

${ }^{1}$ Centro de Biología Molecular y Celular de Enfermedades, Instituto de Investigaciones Científicas y Servicios de Alta Tecnología (INDICASAT-AIP), Edificio 219, Clayton, Ciudad del Saber, República de Panamá. ²Department of Biotechnology, Acharya Nagarjuna University, Guntur, India.

Received: 1 October 2013 Accepted: 24 February 2014

Published: 13 March 2014 


\section{References}

1. WHO: Dementia: A Public Health Priority. Geneva; 2012:112.

2. Glabe CC: Amyloid accumulation and pathogenesis of Alzheimer's disease: significance of monomeric, oligomeric and fibrillar $A \beta$. Subcell Biochem 2005, 38:167-177

3. Sastre M, Klockgether T, Heneka MT: Contribution of inflammatory processes to Alzheimer's disease: molecular mechanisms. Int J Dev Neurosci 2006, 24(2-3):167-176.

4. Hardy J, Selkoe DJ: The amyloid hypothesis of Alzheimer's disease: progress and problems on the road to therapeutics. Science 2002, 297(5580):353-356.

5. Shie FS, LeBoeuf RC, Jin LW: Early intraneuronal $A \beta$ deposition in the hippocampus of APP transgenic mice. Neuroreport 2003, 14(1):123-129.

6. Takahashi RH, Capetillo-Zarate E, Lin MT, Milner TA, Gouras GK: Co-occurrence of Alzheimer's disease $\beta$-amyloid and $\tau$ pathologies at synapses. Neurobiol Aging 2010, 31(7):1145-1152.

7. Lawson LJ, Perry VH, Gordon S: Turnover of resident microglia in the normal adult mouse brain. Neuroscience 1992, 48(2):405-415.

8. Kettenmann H, Hanisch UK, Noda M, Verkhratsky A: Physiology of microglia. Physiol Rev 2011, 91(2):461-553

9. Van Eldik $\sqcup$, Thompson WL, Ralay Ranaivo H, Behanna HA, Martin Watterson D: Glia proinflammatory cytokine upregulation as a therapeutic target for neurodegenerative diseases: function-based and target-based discovery approaches. Int Rev Neurobiol 2007, 82:277-296.

10. Zaheer A, Zaheer S, Thangavel R, Wu Y, Sahu SK, Yang B: Glia maturation factor modulates $\beta$-amyloid-induced glial activation, inflammatory cytokine/chemokine production and neuronal damage. Brain Res 2008, 1208:192-203.

11. Fernandez PL, Britton GB, Rao KS: Potential immunotargets for Alzheimer's disease treatment strategies. J Alzheimers Dis 2013, 33(2):297-312.

12. Crehan H, Hardy J, Pocock J: Microglia, Alzheimer's disease, and complement. Int J Alzheimers Dis 2012, 2012:983640.

13. Moore KJ, El Khoury J, Medeiros LA, Terada K, Geula C, Luster AD, Freeman MW: A CD36-initiated signaling cascade mediates inflammatory effects of ß-amyloid. J Biol Chem 2002, 277(49):47373-47379.

14. Lue LF, Walker DG, Brachova L, Beach TG, Rogers J, Schmidt AM, Stern DM, Yan SD: Involvement of microglial receptor for advanced glycation endproducts (RAGE) in Alzheimer's disease: identification of a cellular activation mechanism. Exp Neurol 2001, 171(1):29-45.

15. Walport MJ: Complement. Second of two parts. N Engl J Med 2001, 344(15):1140-1144.

16. Eikelenboom P, Hack CE, Rozemuller JM, Stam FC: Complement activation in amyloid plaques in Alzheimer's dementia. Virchows Arch B Cell Pathol Ind Mol Patho 1989, 56(4):259-262.

17. Afagh A, Cummings BJ, Cribbs DH, Cotman CW, Tenner AJ: Localization and cell association of C1q in Alzheimer's disease brain. Exp Neurol 1996, 138(1):22-32.

18. Bonifati DM, Kishore U: Role of complement in neurodegeneration and neuroinflammation. Mol Immunol 2007, 44(5):999-1010.

19. Bradt BM, Kolb WP, Cooper NR: Complement-dependent proinflammatory properties of the Alzheimer's disease $\beta$-peptide. J Exp Med 1998, 188(3):431-438.

20. Daborg J, Andreasson U, Pekna M, Lautner R, Hanse E, Minthon L, Blennow K, Hansson O, Zetterberg $H$ : Cerebrospinal fluid levels of complement proteins C3, C4 and CR1 in Alzheimer's disease. J Neural Transm 2012, 119(7):789-797.

21. Lambert JC, Heath S, Even G, Campion D, Sleegers K, Hiltunen M, Combarros O, Zelenika D, Bullido MJ, Tavernier B, Letenneur L, Bettens K, Berr C, Pasquier F, Fiévet N, Barberger-Gateau P, Engelborghs S, De Deyn P, Mateo I, Franck A, Helisalmi S, Porcellini E, Hanon O, European Alzheimer's Disease Initiative I, de Pancorbo MM, Lendon C, Dufouil C, Jaillard C, Leveillard T, Alvarez $V$, et al: Genome-wide association study identifies variants at CLU and CR1 associated with Alzheimer's disease. Nat Genet 2009, 41(10):1094-1099.

22. Biffi A, Anderson CD, Desikan RS, Sabuncu M, Cortellini L, Schmansky N, Salat D, Rosand J: Genetic variation and neuroimaging measures in Alzheimer disease. Arch Neurol 2010, 67(6):677-685.

23. Corneveaux JJ, Myers AJ, Allen AN, Pruzin JJ, Ramirez M, Engel A, Nalls MA, Chen K, Lee W, Chewning K, Villa SE, Meechoovet HB, Gerber JD, Frost D, Benson HL, O'Reilly S, Chibnik LB, Shulman JM, Singleton AB, Craig DW Van Keuren-Jensen KR, Dunckley T, Bennett DA, De Jager PL, Heward C,
Hardy J, Reiman EM, Huentelman MJ: Association of CR1, CLU and PICALM with Alzheimer's disease in a cohort of clinically characterized and neuropathologically verified individuals. Hum Mol Genet 2010, 19(16):3295-3301

24. Zhang Q, Yu JT, Zhu QX, Zhang W, Wu ZC, Miao D, Tan L: Complement receptor 1 polymorphisms and risk of late-onset Alzheimer's disease. Brain Res 2010, 1348:216-221.

25. Crehan H, Hardy J, Pocock J: Blockage of CR1 prevents activation of rodent microglia. Neurobiol Dis 2013, 54:139-149.

26. Rogers J, Li R, Mastroeni D, Grover A, Leonard B, Ahern G, Cao P, Kolody H, Vedders L, Kolb WP, Sabbagh M: Peripheral clearance of amyloid $\beta$ peptide by complement C3-dependent adherence to erythrocytes. Neurobiol Aging 2006, 27(12):1733-1739.

27. Brouwers N, Van Cauwenberghe C, Engelborghs S, Lambert JC, Bettens K, Le Bastard N, Pasquier F, Montoya AG, Peeters K, Mattheijssens M, Vandenberghe R, Deyn PP, Cruts M, Amouyel P, Sleegers K, Van Broeckhoven C: Alzheimer risk associated with a copy number variation in the complement receptor 1 increasing $\mathrm{C} 3 \mathrm{~b} / \mathrm{C} 4 \mathrm{~b}$ binding sites. Mol Psychiatry 2012, 17(2):223-233.

28. Crehan H, Holton P, Wray S, Pocock J, Guerreiro R, Hardy J: Complement receptor 1 (CR1) and Alzheimer's disease. Immunobiology 2012, 217(2):244-250.

29. Strohmeyer R, Ramirez M, Cole GJ, Mueller K, Rogers J: Association of factor $\mathrm{H}$ of the alternative pathway of complement with agrin and complement receptor 3 in the Alzheimer's disease brain. J Neuroimmunol 2002, 131(1-2):135-146.

30. Maier M, Peng Y, Jiang L, Seabrook TJ, Carroll MC, Lemere CA: Complement C3 deficiency leads to accelerated amyloid $\beta$ plaque deposition and neurodegeneration and modulation of the microglia/macrophage phenotype in amyloid precursor protein transgenic mice. J Neurosci 2008, 28(25):6333-6341.

31. Choucair-Jaafar N, Laporte $V$, Levy R, Poindron P, Lombard $Y$, Gies JP: Complement receptor $3(C D 11 \mathrm{~b} / \mathrm{CD} 18)$ is implicated in the elimination of $\beta$-amyloid peptides. Fundam Clin Pharmacol 2011, 25(1):115-122.

32. Fu H, Liu B, Frost JL, Hong S, Jin M, Ostaszewski B, Shankar GM, Costantino IM, Carroll MC, Mayadas TN, Lemere CA: Complement component C3 and complement receptor type 3 contribute to the phagocytosis and clearance of fibrillar A 3 by microglia. Glia 2012, 60(6):993-1003.

33. Zhang D, Hu X, Qian L, Chen SH, Zhou H, Wilson B, Miller DS, Hong JS: Microglial MAC1 receptor and PI3K are essential in mediating $\beta$-amyloid peptide-induced microglial activation and subsequent neurotoxicity. J Neuroinflammation 2011, 8(1):3.

34. Woodruff TM, Ager RR, Tenner AJ, Noakes PG, Taylor SM: The role of the complement system and the activation fragment $\mathrm{C} 5 \mathrm{a}$ in the central nervous system. Neuromolecular Med 2010, 12(2):179-192.

35. Ager RR, Fonseca MI, Chu SH, Sanderson SD, Taylor SM, Woodruff TM, Tenner AJ: Microglial C5aR (CD88) expression correlates with amyloid- $\beta$ deposition in murine models of Alzheimer's disease. J Neurochem 2010, 113(2):389-401.

36. O'Barr S, Cooper NR: The C5a complement activation peptide increases IL-1 $\beta$ and IL- 6 release from amyloid- $\beta$ primed human monocytes: implications for Alzheimer's disease. J Neuroimmunol 2000, 109(2):87-94.

37. Fonseca Ml, Ager RR, Chu SH, Yazan O, Sanderson SD, LaFerla FM, Taylor SM, Woodruff TM, Tenner AJ: Treatment with a C5aR antagonist decreases pathology and enhances behavioral performance in murine models of Alzheimer's disease. J Immunol 2009, 183(2):1375-1383.

38. Fonseca MI, McGuire SO, Counts SE, Tenner AJ: Complement activation fragment $\mathrm{C} 5$ a receptors, $\mathrm{CD} 88$ and $\mathrm{C} 5 \mathrm{~L} 2$, are associated with neurofibrillary pathology. J Neuroinflammation 2013, 10:25

39. Wyss-Coray T, Yan F, Lin AH, Lambris JD, Alexander JJ, Quigg RJ, Masliah E: Prominent neurodegeneration and increased plaque formation in complement-inhibited Alzheimer's mice. Proc Natl Acad Sci USA 2002, 99(16):10837-10842.

40. Nataf S, Stahel PF, Davoust N, Barnum SR: Complement anaphylatoxin receptors on neurons: new tricks for old receptors? Trends Neurosci 1999 22(9):397-402

41. Okun E, Mattson MP, Arumugam TV: Involvement of Fc receptors in disorders of the central nervous system. Neuromolecular Med 2010, 12(2):164-178

42. Song X, Shapiro S, Goldman DL, Casadevall A, Scharff M, Lee SC: Fcy receptor I- and III-mediated macrophage inflammatory protein $1 \mathrm{a}$ 
induction in primary human and murine microglia. Infect Immun 2002, 70(9):5177-5184

43. Song $X$, Tanaka S, Cox D, Lee SC: Fcy receptor signaling in primary human microglia: differential roles of $\mathrm{PI}-3 \mathrm{~K}$ and Ras/ERK MAPK pathways in phagocytosis and chemokine induction. J Leukoc Biol 2004, 75(6):1147-1155

44. Peress NS, Fleit HB, Perillo E, Kuljis R, Pezzullo C: Identification of FcyRI, II and III on normal human brain ramified microglia and on microglia in senile plaques in Alzheimer's disease. J Neuroimmunol 1993, 48(1):71-79.

45. Engelhardt JI, Le WD, Siklos L, Obal I, Boda K, Appel SH: Stereotaxic injection of IgG from patients with Alzheimer disease initiates injury of cholinergic neurons of the basal forebrain. Arch Neurol 2000, 57(5):681-686.

46. Janus C, Pearson J, McLaurin J, Mathews PM, Jiang Y, Schmidt SD, Chishti MA, Horne P, Heslin D, French J, Mount HT, Nixon RA, Mercken M, Bergeron C, Fraser PE, St George-Hyslop P, Westaway D: A $\beta$ peptide immunization reduces behavioural impairment and plaques in a model of Alzheimer's disease. Nature 2000, 408(6815):979-982.

47. Bard F, Cannon C, Barbour R, Burke RL, Games D, Grajeda H, Guido T, Hu K, Huang J, Johnson-Wood K, Khan K, Kholodenko D, Lee M, Lieberburg I, Motter R, Nguyen M, Soriano F, Vasquez N, Weiss K, Welch B, Seubert P, Schenk D, Yednock T: Peripherally administered antibodies against amyloid $\beta$-peptide enter the central nervous system and reduce pathology in a mouse model of Alzheimer disease. Nat Med 2000, 6(8):916-919.

48. Wilcock DM, DiCarlo G, Henderson D, Jackson J, Clarke K, Ugen KE, Gordon MN Morgan D: Intracranially administered anti-A $\beta$ antibodies reduce $\beta$-amyloid deposition by mechanisms both independent of and associated with microglial activation. J Neurosci 2003, 23(9):3745-3751.

49. Das P, Howard V, Loosbrock N, Dickson D, Murphy MP, Golde TE: Amyloid- $\beta$ immunization effectively reduces amyloid deposition in $\mathrm{FcRgamma}^{-1-}$ knock-out mice. J Neurosci 2003, 23(24):8532-8538.

50. Bacskai BJ, Kajdasz ST, McLellan ME, Games D, Seubert P, Schenk D, Hyman BT: Non-Fc-mediated mechanisms are involved in clearance of amyloid- $\beta$ in vivo by immunotherapy. J Neurosci 2002, 22(18):7873-7878.

51. Blennow K, Wallin A, Davidsson P, Fredman P, Gottfries CG, Svennerholm L: Intra-blood-brain-barrier synthesis of immunoglobulins in patients with dementia of the Alzheimer type. Alzheimer Dis Assoc Disord 1990, 4(2):79-86

52. Small GW, Rosenthal M, Tourtellotte WW: Central nervous system IgG synthesis rates in Alzheimer disease: possible differences in early-onset and late-onset subgroups. Alzheimer Dis Assoc Disord 1994, 8(1):29-37.

53. Bouras C, Riederer BM, Kovari E, Hof PR, Giannakopoulos P: Humoral immunity in brain aging and Alzheimer's disease. Brain Res Brain Res Rev 2005, 48(3):477-487.

54. Bouras C, Riederer BM, Hof PR, Giannakopoulos P: Induction of MC-1 immunoreactivity in axons after injection of the Fc fragment of human immunoglobulins in macaque monkeys. Acta Neuropathol 2003, 105(1):58-64.

55. Fernandez-Vizarra P, Lopez-Franco O, Mallavia B, Higuera-Matas A Lopez-Parra V, Ortiz-Munoz G, Ambrosio E, Egido J, Almeida OF, Gomez-Guerrero C: Immunoglobulin G Fc receptor deficiency prevents Alzheimer-like pathology and cognitive impairment in mice. Brain 2012, 135(9):2826-2837.

56. Kam TI, Song S, Gwon Y, Park H, Yan JJ, Im I, Choi JW, Choi TY, Kim J, Song DK, Takai T, Kim YC, Kim KS, Choi SY, Choi S, Klein WL, Yuan J, Jung YK: FcyRllb mediates amyloid- $\beta$ neurotoxicity and memory impairment in Alzheimer's disease. J Clin Invest 2013, 123(7):2791-2802.

57. Morgan D: Immunotherapy for Alzheimer's disease. J Intern Med 2011 269(1):54-63.

58. Delrieu J, Ousset PJ, Caillaud C, Vellas B: 'Clinical trials in Alzheimer's disease': immunotherapy approaches. J Neurochem 2012, 120(Suppl 1):186-193.

59. Lemere CA: Immunotherapy for Alzheimer's disease: hoops and hurdles. Mol Neurodegener 2013, 8(1):36.

60. Diamond B, Huerta PT, Mina-Osorio P, Kowal C, Volpe BT: Losing your nerves? Maybe it's the antibodies. Nat Rev Immunol 2009, 9(6):449-456.

61. Le Y, Gong W, Tiffany HL, Tumanov A, Nedospasov S, Shen W, Dunlop NM, Gao JL, Murphy PM, Oppenheim JJ, Wang JM: Amyloid $\beta_{42}$ activates a G-protein-coupled chemoattractant receptor, FPR-like-1. J Neurosci 2001, 21(2):RC123

62. Le Y, Li B, Gong W, Shen W, Hu J, Dunlop NM, Oppenheim JJ, Wang JM: Novel pathophysiological role of classical chemotactic peptide receptors and their communications with chemokine receptors. Immunol Rev 2000, 177:185-194.

63. Lee MS, Yoo SA, Cho CS, Suh PG, Kim WU, Ryu SH: Serum amyloid A binding to formyl peptide receptor-like 1 induces synovial hyperplasia and angiogenesis. J Immunol 2006, 177(8):5585-5594.

64. Le Y, Ye RD, Gong W, Li J, Iribarren P, Wang JM: Identification of functional domains in the formyl peptide receptor-like 1 for agonist-induced cell chemotaxis. FEBS J 2005, 272(3):769-778.

65. Tiffany HL, Lavigne MC, Cui YH, Wang JM, Leto TL, Gao JL, Murphy PM: Amyloid- $\beta$ induces chemotaxis and oxidant stress by acting at formylpeptide receptor 2, a G protein-coupled receptor expressed in phagocytes and brain. J Biol Chem 2001, 276(26):23645-23652.

66. Yazawa H, Yu ZX, Le Takeda Y, Gong W, Ferrans VJ, Oppenheim JJ, Li CC, Wang JM: $\beta$ amyloid peptide $\left(A \beta_{42}\right)$ is internalized via the $G$-proteincoupled receptor FPRL1 and forms fibrillar aggregates in macrophages. FASEB J 2001, 15(13):2454-2462

67. Ying $G$, Iribarren $P$, Zhou $Y$, Gong $W$, Zhang N, Yu ZX, Le $Y$, Cui $Y$, Wang JM: Humanin, a newly identified neuroprotective factor, uses the $G$ proteincoupled formylpeptide receptor-like-1 as a functional receptor. J Immunol 2004, 172(11):7078-7085.

68. Brandenburg LO, Konrad M, Wruck C, Koch T, Pufe T, Lucius R: Involvement of formyl-peptide-receptor-like-1 and phospholipase $D$ in the internalization and signal transduction of amyloid beta 1-42 in glial cells. Neuroscience 2008, 156(2):266-276.

69. Cui YH, Le Y, Gong W, Proost P, Van Damme J, Murphy WJ, Wang JM: Bacterial lipopolysaccharide selectively up-regulates the function of the chemotactic peptide receptor formyl peptide receptor 2 in murine microglial cells. J Immunol 2002, 168(1):434-442

70. Chen K, Iribarren P, Huang J, Zhang L, Gong W, Cho EH, Lockett S, Dunlop NM, Wang JM: Induction of the formyl peptide receptor 2 in microglia by IFN- $\gamma$ and synergy with CD40 ligand. J Immunol 2007, 178(3):1759-1766

71. Lorton D, Schaller J, Lala A, De Nardin E: Chemotactic-like receptors and $A \beta$ peptide induced responses in Alzheimer's disease. Neurobiol Aging 2000, 21(3):463-473.

72. Krieger M, Herz J: Structures and functions of multiligand lipoprotein receptors: macrophage scavenger receptors and LDL receptor-related protein (LRP). Annu Rev Biochem 1994, 63:601-637.

73. Goldstein JL, Ho YK, Basu SK, Brown MS: Binding site on macrophages that mediates uptake and degradation of acetylated low density lipoprotein, producing massive cholesterol deposition. Proc Natl Acad Sci USA 1979, 76(1):333-337.

74. Brown MS, Basu SK, Falck JR, Ho YK, Goldstein JL: The scavenger cell pathway for lipoprotein degradation: specificity of the binding site that mediates the uptake of negatively-charged LDL by macrophages. J Supramol Struct 1980, 13(1):67-81.

75. Murphy JE, Tedbury PR, Homer-Vanniasinkam S, Walker JH, Ponnambalam S: Biochemistry and cell biology of mammalian scavenger receptors. Atherosclerosis 2005, 182(1):1-15.

76. Ashraf MZ, Gupta N: Scavenger receptors: implications in atherothrombotic disorders. Int J Biochem Cell Bio/ 2011, 43(5):697-700.

77. Coraci IS, Husemann J, Berman JW, Hulette C, Dufour JH, Campanella GK, Luster AD, Silverstein SC, El-Khoury JB: CD36, a class B scavenger receptor, is expressed on microglia in Alzheimer's disease brains and can mediate production of reactive oxygen species in response to $\beta$-amyloid fibrils. Am J Pathol 2002, 160(1):101-112.

78. Godoy B, Murgas P, Tichauer J, Von Bernhardi R: Scavenger receptor class A ligands induce secretion of IL1 $\beta$ and exert a modulatory effect on the inflammatory activation of astrocytes in culture. J Neuroimmunol 2012, 251(1-2):6-13.

79. Murgas $P$, Godoy B, von Bernhardi R: $A \beta$ potentiates inflammatory activation of glial cells induced by scavenger receptor ligands and inflammatory mediators in culture. Neurotox Res 2012, 22(1):69-78.

80. Christie RH, Freeman M, Hyman BT: Expression of the macrophage scavenger receptor, a multifunctional lipoprotein receptor, in microglia associated with senile plaques in Alzheimer's disease. Am J Pathol 1996, 148(2):399-403.

81. Freeman M, Ashkenas J, Rees DJ, Kingsley DM, Copeland NG, Jenkins NA, Krieger M: An ancient, highly conserved family of cysteine-rich protein domains revealed by cloning type I and type II murine macrophage scavenger receptors. Proc Natl Acad Sci USA 1990, 87(22):8810-8814. 
82. Gough PJ, Greaves DR, Gordon S: A naturally occurring isoform of the human macrophage scavenger receptor (SR-A) gene generated by alternative splicing blocks modified LDL uptake. J Lipid Res 1998, 39(3):531-543.

83. Kodama T, Reddy P, Kishimoto C, Krieger M: Purification and characterization of a bovine acetyl low density lipoprotein receptor. Proc Natl Acad Sci USA 1988, 85(23):9238-9242.

84. Coller SP, Paulnock DM: Signaling pathways initiated in macrophages after engagement of type A scavenger receptors. J Leukoc Biol 2001, 70(1):142-148.

85. Hickman SE, Allison EK, El Khoury J: Microglial dysfunction and defective $\beta$-amyloid clearance pathways in aging Alzheimer's disease mice. J Neurosci 2008, 28(33):8354-8360.

86. Crucet M, Wust SJ, Spielmann P, Luscher TF, Wenger RH, Matter CM: Hypoxia enhances lipid uptake in macrophages: role of the scavenger receptors Lox1, SRA, and CD36. Atherosclerosis 2013, 229(1):110-117.

87. Husemann J, Loike JD, Anankov R, Febbraio M, Silverstein SC: Scavenger receptors in neurobiology and neuropathology: their role on microglia and other cells of the nervous system. Glia 2002, 40(2):195-205.

88. Yang CN, Shiao YJ, Shie FS, Guo BS, Chen PH, Cho CY, Chen YJ, Huang FL, Tsay $\mathrm{HJ}$ : Mechanism mediating oligomeric $A \beta$ clearance by naive primary microglia. Neurobiol Dis 2011, 42(3):221-230.

89. Frenkel D, Wilkinson K, Zhao L, Hickman SE, Means TK, Puckett L, Farfara D, Kingery ND, Weiner HL, El Khoury J: Scara1 deficiency impairs clearance of soluble amyloid- $\beta$ by mononuclear phagocytes and accelerates Alzheimer'slike disease progression. Nat Commun 2030, 2013:4.

90. Savill J, Hogg N, Ren Y, Haslett C: Thrombospondin cooperates with CD36 and the vitronectin receptor in macrophage recognition of neutrophils undergoing apoptosis. J Clin Invest 1992, 90(4):1513-1522.

91. Albert ML, Pearce SF, Francisco LM, Sauter B, Roy P, Silverstein RL, Bhardwaj N: Immature dendritic cells phagocytose apoptotic cells via $a_{v} \beta_{5}$ and CD36, and cross-present antigens to cytotoxic T lymphocytes. J Exp Med 1998, 188(7):1359-1368.

92. Harmon CM, Abumrad NA: Binding of sulfosuccinimidyl fatty acids to adipocyte membrane proteins: isolation and amino-terminal sequence of an 88-kD protein implicated in transport of long-chain fatty acids. J Membr Biol 1993, 133(1):43-49.

93. Febbraio M, Hajjar DP, Silverstein RL: CD36: a class B scavenger receptor involved in angiogenesis, atherosclerosis, inflammation, and lipid metabolism. J Clin Invest 2001, 108(6):785-791.

94. Dawson DW, Pearce SF, Zhong R, Silverstein RL, Frazier WA, Bouck NP: CD36 mediates the in vitro inhibitory effects of thrombospondin-1 on endothelial cells. J Cell Biol 1997, 138(3):707-717.

95. Ryeom SW, Silverstein RL, Scotto A, Sparrow JR: Binding of anionic phospholipids to retinal pigment epithelium may be mediated by the scavenger receptor CD36. J Biol Chem 1996, 271(34):20536-20539.

96. Silverstein RL, Baird M, Lo SK, Yesner LM: Sense and antisense cDNA transfection of CD36 (glycoprotein IV) in melanoma cells. Role of CD36 as a thrombospondin receptor. J Biol Chem 1992, 267(23):16607-16612.

97. Armesilla $A L$, Vega MA: Structural organization of the gene for human CD36 glycoprotein. J Biol Chem 1994, 269(29):18985-18991.

98. Hoebe K, Georgel P, Rutschmann S, Du X, Mudd S, Crozat K, Sovath S, Shamel L, Hartung T, Zähringer U, Beutler B: CD36 is a sensor of diacylglycerides. Nature 2005, 433(7025):523-527.

99. Gao D, Ashraf MZ, Kar NS, Lin D, Sayre LM, Podrez EA: Structural basis for the recognition of oxidized phospholipids in oxidized low density lipoproteins by class B scavenger receptors CD36 and SR-BI. J Biol Chem 2010, 285(7):4447-4454.

100. Silverstein RL, Li W, Park YM, Rahaman SO: Mechanisms of cell signaling by the scavenger receptor CD36: implications in atherosclerosis and thrombosis. Trans Am Clin Climatol Assoc 2010, 121:206-220.

101. Alessio M, Greco NJ, Primo L, Ghigo D, Bosia A, Tandon NN, Ockenhouse CF, Jamieson GA, Malavasi F: Platelet activation and inhibition of malarial cytoadherence by the anti-CD36 IgM monoclonal antibody NL07. Blood 1993, 82(12):3637-3647.

102. El Khoury JB, Moore KJ, Means TK, Leung J, Terada K, Toft M, Freeman MW Luster AD: CD36 mediates the innate host response to $\beta$-amyloid. J Exp Med 2003, 197(12):1657-1666.

103. Bornemann KD, Wiederhold KH, Pauli C, Ermini F, Stalder M, Schnell L, Sommer B, Jucker M, Staufenbiel M: A $\beta$-induced inflammatory processes in microglia cells of APP23 transgenic mice. Am J Pathol 2001, 158(1):63-73.
104. Ricciarelli R, D’Abramo C, Zingg JM, Giliberto L, Markesbery W, Azzi A, Marinari UM, Pronzato MA, Tabaton M: CD36 overexpression in human brain correlates with $\beta$-amyloid deposition but not with Alzheimer's disease. Free Radic Biol Med 2004, 36(8):1018-1024.

105. Bamberger ME, Harris ME, McDonald DR, Husemann J, Landreth GE: A cell surface receptor complex for fibrillar $\beta$-amyloid mediates microglial activation. J Neurosci 2003, 23(7):2665-2674.

106. Stewart CR, Stuart LM, Wilkinson K, van Gils JM, Deng J, Halle A, Rayner KJ, Boyer L, Zhong R, Frazier WA, Lacy-Hulbert A, El Khoury J, Golenbock DT, Moore KJ: CD36 ligands promote sterile inflammation through assembly of a Toll-like receptor 4 and 6 heterodimer. Nat Immunol 2010, 11(2):155-161.

107. Wilkinson K, Boyd JD, Glicksman M, Moore KJ, El Khoury J: A high content drug screen identifies ursolic acid as an inhibitor of amyloid $\beta$ protein interactions with its receptor CD36. J Biol Chem 2011, 286(40):34914-34922.

108. Neeper M, Schmidt AM, Brett J, Yan SD, Wang F, Pan YC, Elliston K, Stern D Shaw A: Cloning and expression of a cell surface receptor for advanced glycosylation end products of proteins. J Biol Chem 1992, 267(21):14998-15004.

109. Leclerc E, Fritz G, Vetter SW, Heizmann CW: Binding of S100 proteins to RAGE: an update. Biochim Biophys Acta 2009, 1793(6):993-1007.

110. Akirav EM, Preston-Hurlburt P, Garyu J, Henegariu O, Clynes R, Schmidt AM, Herold KC: RAGE expression in human T cells: a link between environmental factors and adaptive immune responses. PLoS One 2012, 7(4):e34698.

111. Fang F, Lue LF, Yan S, Xu H, Luddy JS, Chen D, Walker DG, Stern DM, Schmidt AM, Chen JX, Yan SS: RAGE-dependent signaling in microglia contributes to neuroinflammation, $A \beta$ accumulation, and impaired learning/memory in a mouse model of Alzheimer's disease. FASEB J 2010, 24(4):1043-1055

112. Alexiou P, Chatzopoulou M, Pegklidou K, Demopoulos VJ: RAGE: a multiligand receptor unveiling novel insights in health and disease. Curr Med Chem 2010, 17(21):2232-2252.

113. Deane R, Du Yan S, Submamaryan RK, LaRue B, Jovanovic S, Hogg E, Welch D, Manness L, Lin C, Yu J, Zhu H, Ghiso J, Frangione B, Stern A, Schmidt AM, Armstrong DL, Arnold B, Liliensiek B, Nawroth P, Hofman F, Kindy M, Stern D, Zlokovic B: RAGE mediates amyloid- $\beta$ peptide transport across the bloodbrain barrier and accumulation in brain. Nat Med 2003, 9(7):907-913.

114. Moreira PI, Duarte Al, Santos MS, Rego AC, Oliveira CR: An integrative view of the role of oxidative stress, mitochondria and insulin in Alzheimer's disease. J Alzheimers Dis 2009, 16(4):741-761.

115. Reddy VP, Zhu X, Perry G, Smith MA: Oxidative stress in diabetes and Alzheimer's disease. J Alzheimers Dis 2009, 16(4):763-774.

116. Origlia N, Bonadonna C, Rosellini A, Leznik E, Arancio O, Yan SS, Domenici L: Microglial receptor for advanced glycation end product-dependent signal pathway drives $\beta$-amyloid-induced synaptic depression and long-term depression impairment in entorhinal cortex. J Neurosci 2010, 30(34):11414-11425

117. Origlia N, Righi M, Capsoni S, Cattaneo A, Fang F, Stern DM, Chen JX, Schmidt AM, Arancio O, Yan SD, Domenici L: Receptor for advanced glycation end product-dependent activation of p38 mitogen-activated protein kinase contributes to amyloid- $\beta$-mediated cortical synaptic dysfunction. J Neurosci 2008, 28(13):3521-3530.

118. Onyango IG, Tuttle JB, Bennett JP Jr: Altered intracellular signaling and reduced viability of Alzheimer's disease neuronal cybrids is reproduced by $\beta$-amyloid peptide acting through receptor for advanced glycation end products (RAGE). Mol Cell Neurosci 2005, 29(2):333-343.

119. Slowik A, Merres J, Elfgen A, Jansen S, Mohr F, Wruck CJ, Pufe T, Brandenburg LO: Involvement of formyl peptide receptors in receptor for advanced glycation end products (RAGE) - and amyloid beta 1-42-induced signal transduction in glial cells. Mol Neurodegener 2012, 7:55.

120. Du H, Li P, Wang J, Qing X, Li W: The interaction of amyloid $\beta$ and the receptor for advanced glycation endproducts induces matrix metalloproteinase-2 expression in brain endothelial cells. Cell Mol Neurobiol 2012, 32(1):141-147.

121. Yan SD, Chen X, Fu J, Chen M, Zhu H, Roher A, Slattery T, Zhao L, Nagashima M, Morser J, Migheli A, Nawroth P, Stern D, Schmidt AM: RAGE and amyloid- $\beta$ peptide neurotoxicity in Alzheimer's disease. Nature 1996, 382(6593):685-691

122. Sabbagh MN, Agro A, Bell J, Aisen PS, Schweizer E, Galasko D: PF-04494700, an oral inhibitor of receptor for advanced glycation end products (RAGE), in Alzheimer disease. Alzheimer Dis Assoc Disord 2011, 25(3):206-212. 
123. Deane R, Singh I, Sagare AP, Bell RD, Ross NT, LaRue B, Love R, Perry $S$, Paquette N, Deane RJ, Thiyagarajan M, Zarcone T, Fritz G, Friedman AE Miller BL, Zlokovic BV: A multimodal RAGE-specific inhibitor reduces amyloid $\beta$-mediated brain disorder in a mouse model of Alzheimer disease. J Clin Invest 2012, 122(4):1377-1392.

124. Morisato D, Anderson KV: The spätzle gene encodes a component of the extracellular signaling pathway establishing the dorsal-ventral pattern of the Drosophila embryo. Cell 1994, 76(4):677-688.

125. Lemaitre B, Nicolas E, Michaut L, Reichhart JM, Hoffmann JA: The dorsoventral regulatory gene cassette spätzle/Toll/cactus controls the potent antifungal response in Drosophila adults. Cell 1996, 86(6):973-983.

126. Lehnardt S: Innate immunity and neuroinflammation in the CNS: the role of microglia in Toll-like receptor-mediated neuronal injury. Glia 2010, 58(3):253-263.

127. Hanke ML, Kielian T: Toll-like receptors in health and disease in the brain: mechanisms and therapeutic potential. Clin Sci (Lond) 2011, 121(9):367-387.

128. Yamamoto $M$, Takeda $\mathrm{K}$ : Current views of toll-like receptor signaling pathways. Gastroenterol Res Pract 2010, 2010:240365.

129. Olson JK, Miller SD: Microglia initiate central nervous system innate and adaptive immune responses through multiple TLRs. J Immunol 2004, 173(6):3916-3924

130. Frank S, Copanaki E, Burbach GJ, Muller UC, Deller T: Differential regulation of toll-like receptor mRNAs in amyloid plaque-associated brain tissue of aged APP23 transgenic mice. Neurosci Lett 2009, 453(1):41-44.

131. Jin JJ, Kim HD, Maxwell JA, Li L, Fukuchi K: Toll-like receptor 4-dependent upregulation of cytokines in a transgenic mouse model of Alzheimer's disease. J Neuroinflammation 2008, 5:23.

132. Tahara K, Kim HD, Jin JJ, Maxwell JA, Li L, Fukuchi K: Role of toll-like receptor signalling in A $\beta$ uptake and clearance. Brain 2006, 129(11):3006-3019.

133. Lien E, Means TK, Heine H, Yoshimura A, Kusumoto S, Fukase K, Fenton MJ, Oikawa M, Qureshi N, Monks B, Finberg RW, Ingalls RR, Golenbock DT: Toll-like receptor 4 imparts ligand-specific recognition of bacterial lipopolysaccharide. J Clin Invest 2000, 105(4):497-504.

134. Erridge C: Endogenous ligands of TLR2 and TLR4: agonists or assistants? J Leukoc Biol 2010, 87(6):989-999.

135. Noreen M, Shah MA, Mall SM, Choudhary S, Hussain T, Ahmed I, Jalil SF, Raza MI: TLR4 polymorphisms and disease susceptibility. Inflamm Res 2012, 61(3):177-188.

136. Liu T, Gao YJ, Ji RR: Emerging role of Toll-like receptors in the control of pain and itch. Neurosci Bull 2012, 28(2):131-144.

137. Song M, Jin J, Lim JE, Kou J, Pattanayak A, Rehman JA, Kim HD, Tahara K, Lalonde R, Fukuchi K: TLR4 mutation reduces microglial activation, increases $A \beta$ deposits and exacerbates cognitive deficits in a mouse model of Alzheimer's disease. J Neuroinflammation 2011, 8:92.

138. Walter S, Letiembre M, Liu Y, Heine H, Penke B, Hao W, Bode B, Manietta N, Walter J, Schulz-Schuffer W, Fassbender K: Role of the toll-like receptor 4 in neuroinflammation in Alzheimer's disease. Cell Physiol Biochem 2007, 20(6):947-956

139. Michaud JP, Halle $M$, Lampron A, Theriault $P$, Prefontaine $P$, Filali $M$ Tribout-Jover P, Lanteigne AM, Jodoin R, Cluff C, Brichard V, Palmantier R, Pilorget $A$, Larocque $D$, Rivest S: Toll-like receptor 4 stimulation with the detoxified ligand monophosphoryl lipid A improves Alzheimer's diseaserelated pathology. Proc Natl Acad Sci USA 2013, 110(5):1941-1946.

140. Bsibsi M, Ravid R, Gveric D, van Noort JM: Broad expression of Toll-like receptors in the human central nervous system. J Neuropathol Exp Neurol 2002, 61(11):1013-1021.

141. Chen K, Iribarren P, Hu J, Chen J, Gong W, Cho EH, Lockett S, Dunlop NM, Wang JM: Activation of Toll-like receptor 2 on microglia promotes cell uptake of Alzheimer disease-associated amyloid $\beta$ peptide. J Biol Chem 2006, 281(6):3651-3659.

142. Richard KL, Filali M, Prefontaine $P$, Rivest S: Toll-like receptor 2 acts as a natural innate immune receptor to clear amyloid $\beta_{1-42}$ and delay the cognitive decline in a mouse model of Alzheimer's disease. J Neurosci 2008, 28(22):5784-5793.

143. Jana M, Palencia CA, Pahan K: Fibrillar amyloid- $\beta$ peptides activate microglia via TLR2: implications for Alzheimer's disease. J Immunol 2008, 181(10):7254-7262.

144. Liu S, Liu Y, Hao W, Wolf L, Kiliaan AJ, Penke B, Rube CE, Walter J, Heneka MT, Hartmann T, Menger MD, Fassbender K: TLR2 is a primary receptor for Alzheimer's amyloid $\beta$ peptide to trigger neuroinflammatory activation. J Immunol 2012, 188(3):1098-1107.
145. Reed-Geaghan EG, Savage JC, Hise AG, Landreth GE: CD14 and toll-like receptors 2 and 4 are required for fibrillar $A \beta$-stimulated microglial activation. J Neurosci 2009, 29(38):11982-11992.

146. Bachstetter AD, Xing B, de Almeida L, Dimayuga ER, Watterson DM Van Eldik $\sqcup$ : Microglial p38a MAPK is a key regulator of proinflammatory cytokine up-regulation induced by toll-like receptor (TLR) ligands or betaamyloid (Aß). J Neuroinflammation 2011, 8:79.

147. Iribarren P, Chen K, Hu J, Gong W, Cho EH, Lockett S, Uranchimeg B, Wang JM: CpG-containing oligodeoxynucleotide promotes microglial cell uptake of amyloid $\beta$ 1-42 peptide by up-regulating the expression of the G-proteincoupled receptor mFPR2. FASEB J 2005, 19(14):2032-2034.

148. Doi Y, Mizuno T, Maki Y, Jin S, Mizoguchi H, Ikeyama M, Doi M, Michikawa M, Takeuchi $H$, Suzumura A: Microglia activated with the toll-like receptor 9 ligand $C p G$ attenuate oligomeric amyloid $\beta$ neurotoxicity in in vitro and in vivo models of Alzheimer's disease. Am J Pathol 2009, 175(5):2121-2132

149. Halle A, Hornung V, Petzold GC, Stewart CR, Monks BG, Reinheckel T, Fitzgerald KA, Latz E, Moore KJ, Golenbock DT: The NALP3 inflammasome is involved in the innate immune response to amyloid- $\beta$. Nat Immunol 2008, 9(8):857-865

150. Martinon F, Petrilli V, Mayor A, Tardivel A, Tschopp J: Gout-associated uric acid crystals activate the NALP3 inflammasome. Nature 2006, 440(7081):237-241.

151. Kuroda E, Ishii K, Uematsu S, Ohata K, Coban C, Akira S, Aritake K, Urade Y, Morimoto Y: Silica crystals and aluminum salts regulate the production of prostaglandin in macrophages via NALP3 inflammasome-independent mechanisms. Immunity 2011, 34(4):514-526.

152. Lamkanfi M, Walle LV, Kanneganti TD: Deregulated inflammasome signaling in disease. Immunol Rev 2011, 243(1):163-173.

153. Forloni G, Demicheli F, Giorgi S, Bendotti C, Angeretti N: Expression of amyloid precursor protein mRNAs in endothelial, neuronal and glial cells: modulation by interleukin-1. Brain Res Mol Brain Res 1992, 16(1-2):128-134.

154. Heneka MT, Kummer MP, Stutz A, Delekate A, Schwartz S, Vieira-Saecker A, Griep A, Axt D, Remus A, Tzeng TC, Gelpi E, Halle A, Korte M, Latz E, Golenbock DT: NLRP3 is activated in Alzheimer's disease and contributes to pathology in APP/PS1 mice. Nature 2013, 493(7434):674-678.

155. Sheedy FJ, Grebe A, Rayner KJ, Kalantari P, Ramkhelawon B, Carpenter SB, Becker CE, Ediriweera HN, Mullick AE, Golenbock DT, Stuart LM, Latz E, Fitzgerald KA, Moore KJ: CD36 coordinates NLRP3 inflammasome activation by facilitating intracellular nucleation of soluble ligands into particulate ligands in sterile inflammation. Nat Immunol 2013, 14(8):812-820.

156. Bertram L, Lange C, Mullin K, Parkinson M, Hsiao M, Hogan MF, Schjeide BM, Hooli B, Divito J, lonita I, Jiang H, Laird N, Moscarillo T, Ohlsen KL, Elliott K, Wang X, Hu-Lince D, Ryder M, Murphy A, Wagner SL, Blacker D, Becker KD, Tanzi RE: Genome-wide association analysis reveals putative Alzheimer's disease susceptibility loci in addition to APOE. Am J Hum Genet 2008, 83(5):623-632

157. Crocker PR, Paulson JC, Varki A: Siglecs and their roles in the immune system. Nat Rev Immunol 2007, 7(4):255-266.

158. Garnache-Ottou F, Chaperot L, Biichle S, Ferrand C, Remy-Martin JP, Deconinck E, de Tailly PD, Bulabois B, Poulet J, Kuhlein E, Jacob MC, Salaun V, Arock M, Drenou B, Schillinger F, Seilles E, Tiberghien P, Bensa JC, Plumas J, Saas P: Expression of the myeloid-associated marker CD33 is not an exclusive factor for leukemic plasmacytoid dendritic cells. Blood 2005, 105(3):1256-1264.

159. Bradshaw EM, Chibnik LB, Keenan BT, Ottoboni L, Raj T, Tang A, Rosenkrantz LL, Imboywa S, Lee M, Von Korff A, Alzheimer Disease Neuroimaging Initiative, Morris MC, Evans DA, Johnson K, Sperling RA Schneider JA, Bennett DA, De Jager P: CD33 Alzheimer's disease locus: altered monocyte function and amyloid biology. Nat Neurosc 2013, 16(7):848-850.

160. Griciuc A, Serrano-Pozo A, Parrado AR, Lesinski AN, Asselin CN, Mullin K, Hooli B, Choi SH, Hyman BT, Tanzi RE: Alzheimer's disease risk gene CD33 inhibits microglial uptake of amyloid beta. Neuron 2013, 78(4):631-643.

161. Takahashi K, Rochford CD, Neumann H: Clearance of apoptotic neurons without inflammation by microglial triggering receptor expressed on myeloid cells-2. J Exp Med 2005, 201(4):647-657.

162. Hsieh CL, Koike M, Spusta SC, Niemi EC, Yenari M, Nakamura MC, Seaman WE: A role for TREM2 ligands in the phagocytosis of apoptotic neuronal cells by microglia. J Neurochem 2009, 109(4):1144-1156. 
163. Sessa G, Podini P, Mariani M, Meroni A, Spreafico R, Sinigaglia F, Colonna M, Panina P, Meldolesi J: Distribution and signaling of TREM2/DAP12, the receptor system mutated in human polycystic lipomembraneous osteodysplasia with sclerosing leukoencephalopathy dementia. Eur $J$ Neurosci 2004, 20(10):2617-2628.

164. Frank S, Burbach GJ, Bonin M, Walter M, Streit W, Bechmann I, Deller T: TREM2 is upregulated in amyloid plaque-associated microglia in aged APP23 transgenic mice. Glia 2008, 56(13):1438-1447.

165. Jonsson T, Stefansson H, Steinberg S, Jonsdottir I, Jonsson PV, Snaedal J, Bjornsson S, Huttenlocher J, Levey Al, Lah JJ, Rujescu D, Hampel H, Giegling I, Andreassen OA, Engedal K, Ulstein I, Djurovic S, Ibrahim-Verbaas C, Hofman A, Ikram MA, van Duijn CM, Thorsteinsdottir U, Kong A, Stefansson K: Variant of TREM2 associated with the risk of Alzheimer's disease. N Engl J Med 2013, 368(2):107-116.

166. Guerreiro R, Wojtas A, Bras J, Carrasquillo M, Rogaeva E, Majounie E, Cruchaga C, Sassi C, Kauwe JS, Lupton MK, Ryten M, Brown K, Lowe J, Ridge PG, Hammer MB, Wakutani Y, Hazrati L, Proitsi P, Newhouse S, Lohmann E, Erginel-Unaltuna N, Medway C, Hanagasi H, Troakes C, Gurvit H, Bilgic B, Al-Sarraj S, Benitez B, Cooper B, Carrell D, et al: TREM2 variants in Alzheimer's disease. N Eng/ J Med 2013, 368(2):117-127.

167. Braun BJ, Slowik A, Leib SL, Lucius R, Varoga D, Wruck CJ, Jansen S, Podschun R, Pufe T, Brandenburg LO: The formyl peptide receptor like-1 and scavenger receptor MARCO are involved in glial cell activation in bacterial meningitis. J Neuroinflammation 2011, 8(1):11.

doi:10.1186/1742-2094-11-48

Cite this article as: Doens and Fernández: Microglia receptors and their implications in the response to amyloid $\beta$ for Alzheimer's disease pathogenesis. Journal of Neuroinflammation 2014 11:48.

\section{Submit your next manuscript to BioMed Central and take full advantage of:}

- Convenient online submission

- Thorough peer review

- No space constraints or color figure charges

- Immediate publication on acceptance

- Inclusion in PubMed, CAS, Scopus and Google Scholar

- Research which is freely available for redistribution 